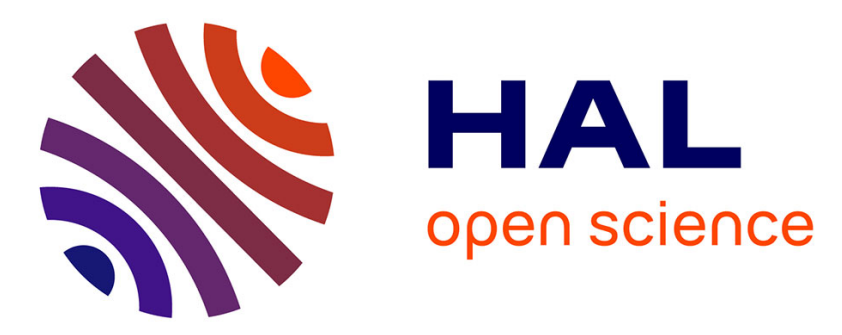

\title{
The Study of Annealed Epitaxial Ferrite-Garnet Thin Films by Means of Ferromagnetic Resonance
}

\author{
B. Padlyak
}

\section{To cite this version:}

B. Padlyak. The Study of Annealed Epitaxial Ferrite-Garnet Thin Films by Means of Ferromagnetic Resonance. Journal de Physique IV Proceedings, 1997, 07 (C1), pp.C1-503-C1-504. 10.1051/jp4:19971206 . jpa-00254857

\section{HAL Id: jpa-00254857 https://hal.science/jpa-00254857}

Submitted on 1 Jan 1997

HAL is a multi-disciplinary open access archive for the deposit and dissemination of scientific research documents, whether they are published or not. The documents may come from teaching and research institutions in France or abroad, or from public or private research centers.
L'archive ouverte pluridisciplinaire HAL, est destinée au dépôt et à la diffusion de documents scientifiques de niveau recherche, publiés ou non, émanant des établissements d'enseignement et de recherche français ou étrangers, des laboratoires publics ou privés. 


\title{
The Study of Annealed Epitaxial Ferrite-Garnet Thin Films by Means of Ferromagnetic Resonance
}

\author{
B. Padlyak
}

\author{
Ivan Franko State University, Department of Physics, 50 Dragomanov str., 290005 Lviv, Ukraine
}

\begin{abstract}
The variations of FMR spectra, domain structure and basic magnetic parameters the thin epitaxial ferrite-garnet films of $(\mathrm{Y}, \mathrm{Sm}, \mathrm{Lu}, \mathrm{Ca})_{3}(\mathrm{Fe}, \mathrm{Ge})_{5} \mathrm{O}_{12}$ composition resulted from air high-temperature annealing are investigated. On the basis of experimental data analysis was shown that the annealing at $T_{a}=1100^{\circ} \mathrm{C}, t_{a}>8 \mathrm{hrs}$ and $T_{a}=1150^{\circ} \mathrm{C}, 1200^{\circ} \mathrm{C}, t_{a}=2 \div 10$ hrs leads to creation of the magnetic transitional layer at the film-substrate boundary. The basic magnetic parameters of films and transitional layers are determined from the FMR spectra. The nature and the formation mechanism of the magnetic transitional layer are discussed.
\end{abstract}

\section{INTRODUCTION}

At present time the thin epitaxial magnetic films on the basis of substituted yttrium iron garnet (YIG) (e.g. films of $(\mathrm{Y}, \mathrm{Sm}, \mathrm{Lu}, \mathrm{Ca})_{3}(\mathrm{Fe}, \mathrm{Ge})_{5} \mathrm{O}_{12}$ compositions or films with $\mathrm{Ca}-\mathrm{Ge}$-substitution) widely used in the magnetic bubbles technology. In the films of $(\mathrm{Y}, \mathrm{Sm}, \mathrm{Lu}, \mathrm{Ca})_{3}(\mathrm{Fe}, \mathrm{Ge})_{5} \mathrm{O}_{12}$ compositions the $\mathrm{Ge}^{4+}$ ions were used for substitution of $\mathrm{Fe}^{3+}$ ions in tetrahedral sites of garnet structure and $\mathrm{Ca}^{2+}$ ions were added to the composition for electrical compensation. In connection with the narrow region of homogeneity of the Ca-Ge -substituted system in comparison with Ga-substituted system the any deviations from stoichiometric compositions lead to significant changes of the films magnetic parameters for both epitaxy process and postepitaxial high-temperature annealing. Despite a nimber of papers [1-4] devoted to exploration of hightemperature annealing effect on magnetic properties of epitaxial ferrite-garnet films, the nature of annealing process is studied insufficiently.

\section{EXPERIMENTAL PROCEDURE}

Thin ferrite-garnet films of $(\mathrm{Y}, \mathrm{Sm}, \mathrm{Lu}, \mathrm{Ca})_{3}(\mathrm{Fe}, \mathrm{Ge})_{5} \mathrm{O}_{12}$ compositions were grown by the standard liquid phase epitaxy method on the gadolinium-gallium garnet (GGG) substrate materials of (111) crystallographic orientation. The classical furnace annealing in air was carried out at $T_{2}=1100,1150$ and $1200^{\circ} \mathrm{C}$ during $2 \div 10$ hrs. Annealing included the heating of samples up to $T_{3}$, standing at $t_{2}$ and slow inertial cooling down to room temperature. After each stage of films annealing the FMR spectra were recorded using an RE-1306 $\mathrm{X}$-band commercial EPR spectrometer operating in the high-frequency $(100 \mathrm{kHz})$ modulation mode of magnetic field at $300 \mathrm{~K}$.

\section{EXPERIMENTAL RESULTS AND DISCUSSION}

Investigations of the FMR spectra showed that the air annealing of films at $T_{a}=1100^{\circ} \mathrm{C}$ during $1 \div 7$ hours leads to shift of the resonance line in lower (for $\mathrm{H} \perp[111]$ ) and higher (for $\mathrm{H} \|[111]$ ) magnetic fields relatively to their initial positions (Fig. 1 a,b). The FMR lines shifts are resulted with the variations of the following films parameters: magneto-mechanical ratio $\gamma$, uniaxial anisotropy constant $K_{u}$, exchange interaction constant $A$, magnetization of saturation $4 \pi M_{s}$, Gilbert dissipation parameter $\alpha$ etc. The character of these parameters variations caused by heat treatment is well known [1-4]. Besides of lines shifts, the slight rise of the FMR line-width correlated with increasing of the annealing temperature and duration was observed. This effect results from films structure homogeneity decreasing [4]. The annealing at $T_{a}=1100^{\circ} \mathrm{C}, t>8$ hrs and $T$ $=1150^{\circ} \mathrm{C}, 1200^{\circ} \mathrm{C}, \mathrm{t}=2 \div 10$ hrs leads to creation of the transitional magnetic layer (thickness is $\cong 0.3 \mu \mathrm{m}$ ), which is revealed in the FMR spectra by occurence of additional relatively narrow line (Line 2, Fig. 1c). The typical FMR line-width for films of $(\mathrm{Y}, \mathrm{Sm}, \mathrm{Lu}, \mathrm{Ca})_{3}(\mathrm{Fe}, \mathrm{Ge})_{5} \mathrm{O}_{12}$ composition is $300 \div 400 \mathrm{Oe}$, while the width of additional line is $70 \div 100 \mathrm{Oe}$. For some samples the spin-wave resonance peaks (Fig. 2) were observed, caused by the films inhomogeneity on whole thickness. The very narrow lines, which were observed on the FMR line of basic layer (Lines 3, Fig. Ic) are interpreted as a spin-waves surface modes, connected with surface inhomogeneities of films $[5,6]$. The $\gamma$ and $\alpha$ parameters of basic layer are larger than those of the transitional one (Table 1). 


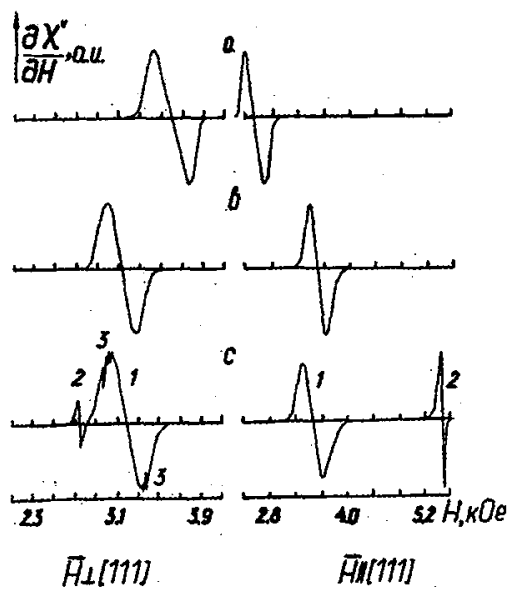

Figure 1: The variations of FMR spectra of the typical ferrite-garnet films resulted from air high-temperature annealing; a)initial FMR spectra;b)FMR spectra after annealing at $\left.T_{a}=1100^{\circ} \mathrm{C}, t_{a}=3 \mathrm{hrs} ; c\right) F M R$ spectra after annealing at $\mathrm{T}_{\mathrm{a}}=1150^{\circ} \mathrm{C}, \mathrm{t}_{\mathrm{a}}=3 \mathrm{hrs}$.

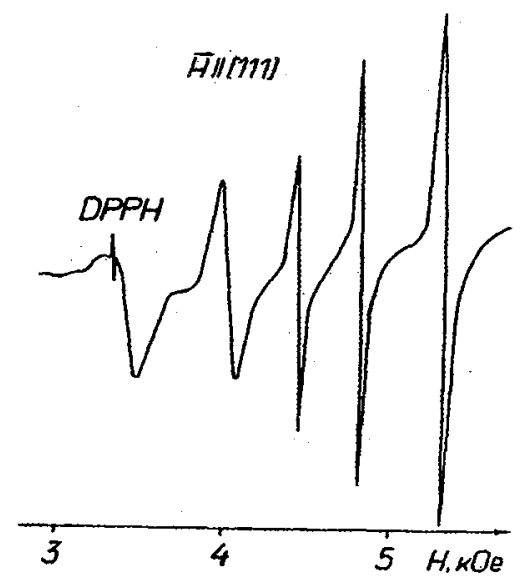

Figure 2: Spin-wave resonance spectrum of the films after annealing in air at $T_{a}=1200^{\circ} \mathrm{C}, t_{a}=4$ hrs recording at room temperature.

That evidenced about the presence in transitional layer of the considerable quantity of rare-earth ions with smaller orbital magnetic momentum and larger spin-lattice relaxation time than for $\mathrm{Sm}^{3+}\left({ }^{6} \mathrm{H}_{5 / 2}\right)$. Such ions may be $\operatorname{Gd}^{3+}\left({ }^{8} \mathrm{~S}_{7 / 2}\right)$, which diffuse from substrate into the film during the thermal annealing process and form the $\{c\}$-sublattice of transitional layer. The values of $\left(H_{k}-4 \pi M_{s}\right)$ parameter (Table 1) show that the magnetic anisotropy of transitional layer has a plane type and uniaxial anisotropy field of basic film is strongly decreased.

Table 1.The basic magnetic parameters of $(\mathrm{Y}, \mathrm{Sm}, \mathrm{Lu}, \mathrm{Ca})_{3}(\mathrm{Fe}, \mathrm{Ge})_{5} \mathrm{O}_{12}$ films and transitional layers after annealing in air at $\mathrm{T}_{\mathrm{a}}=1150^{\circ} \mathrm{C}, \mathrm{t}_{\mathrm{a}}=4 \mathrm{hrs}$, determined from FMR spectra at room temperature.

\begin{tabular}{|c|ccc|ccc|}
\hline Number of a sample & \multicolumn{3}{|c|}{2} & \multicolumn{2}{c|}{3} & \multicolumn{3}{c|}{ Transitional layers } \\
\hline Parameters & \multicolumn{3}{|c|}{ Basic films } & \multicolumn{3}{c|}{3} \\
\hline$\gamma, 10^{-7}($ Oexc) & & & 1.753 & 1.710 & 1.642 \\
\hline$\left(H_{k}-4 \pi M_{s}\right), \mathrm{Oe}$ & 1.805 & 1.806 & 1.795 & -965 & -1682 & -1936 \\
\hline$\alpha$ & 20 & 51 & 40 & 0.011 & 0.015 & 0.013 \\
\hline
\end{tabular}

On the basis of obtained results the nature and formation mechanism of the transitional layer in annealed ferrite-garnet films may be interpreted as follows. It is known that nonstationary initial stage of epitaxial grown films leads to formation of the first transitional layer at the film-substrate boundary with a little difference from basic film chemical composition and magnetic parameters, that does not allow to find it out by FMR and magneto-optical methods. The additional inhomogeneity of films arised at thermal annealing process through the mutual diffusion of non-magnetic, rare-earth and $\mathrm{Fe}^{3+}$ ions at the film-substrate boundary. Such cation redistribution leads to decreasing of uniaxial anisotropy constant $K_{u}$ down to value near to cubic anisotropy constant $K_{1}$ and to essential changes of other magnetic parameters of films. Longterm annealing leads to formation in the films of well-expressed magnetic layers (transitional and basic) with different total magnetization, which is displayed in FMR spectra.

The preliminary study showed the different character of temperature dependences of the FMR field and the line-width for the basic films and their transitional diffuse layers. The temperature dependences of FMR spectra of the basic films and diffuse layers are defined mainly by the $\mathrm{Sm}^{3+}$ and $\mathrm{Gd}^{3+}$ ions of $\{\mathrm{c}\}-$ sublattice respectively and can be described by the De Gennes-Kittel-Portis theory [7].

\section{References}

[1] Le Craw R.C., Georgy E.M., Wolfe D., Appl. Phys. Letters 24 (1974) 573-574.

[2] Enoch R.D., Jones M.E., Murrel D.L., Fiddument P.J., Watters D.G., J.Appl.Phys. 47 (1976) $2705-2709$.

[3] Vittoria C., IEEE Trans. Magn. 18 (1982) 1289-1291.

[4] Nosenko A.E., Volzhenskaya L.G., Padlyak B.V., Zorenko Yu.V., Ukr. Fiz. Zhum. 28 (1983) 1850-1853.

[5] Yu J.T., Turk R.A., Wigen P.E., Phys. Rev. B11 (1975) 420-434.

[6] Ramer O.G., Wilts C.H., Phys.Stat.Sol. (b)79 (1977) 313-320.

[7] De-Gennes P.-G., Kittel C., Portis A.M. Phys. Rev: 116 (1959) 323-329. 